\title{
LEGAL STATUS OF THE CHIEF OF THE NATIONAL POLICE DEPARTMENT OF UKRAINE
}

\section{Izbash K. S.}

The chief, as a person empowered with authority and who has some influence over subordinates, is a central figure in any team. A chief is a profession whose need arises when work becomes collective. He is the manager who must implement the management strategy, consolidate the efforts of his subordinates to solve important management tasks, while using his power. Unlike other categories of management staff, executives are a group of officials who are delegated rights and responsibilities of authority.

In accordance with the European standards and tasks of a legal democratic state and in the current conditions of reforming the system of the Ministry of Internal Affairs of Ukraine, the personnel of the bodies of the National Police, in particular, the leadership of these bodies, are of great importance. Today, the effectiveness of law enforcement agencies, including the National Police, in protecting the rights and freedoms of the individual and the citizen, combating crime and ensuring law and order in the country, is to develop new approaches and models for the formation of senior management, with due consideration for better international experience.

The urgent need and basis for the further development and improvement of the system of the National Police of our country is the quality and transparency of selection for senior police positions, professionalism and mastery of the chiefs of the newest forms of management of bodies and units of the National Police of Ukraine. The necessity and urgency of solving the problems of management of the bodies and units of the National Police of Ukraine impose strict requirements for their managers regarding their professional and personal qualities. Thus, research into the legal status of chiefs of bodies and units of the National Police of Ukraine, as well as the development of proposals for its improvement, are becoming increasingly relevant.

Problems of managerial activity of chiefs of bodies and divisions of the National Police of Ukraine have been the subject of research of many scientists, in particular: Bandurki O.M., Divak M.M., Kisil Z.R., Klochko A.M., Kovalyova M.V., Krischenko A.E., Kudri V.O., Matyukhina N.P., Petkova S.V., Plishkina V.M., Sokurenka V.V., Shatravy S.O., Yarmisch O.N. At the same time, despite the numerous conceptual approaches to solving it, the problem of staffing of the National 
Police of Ukraine remains open. Many important issues have not been resolved at all, including the role and importance of the chief in the activities of bodies and units of the National Police of Ukraine. However, significant shifts in the workforce of a number of post-Soviet states have been made possible by techniques tested in leading countries in the world.

\section{Theoretical approaches to definition of the chief, cadre and personnel}

The dynamic changes that have taken place in Ukrainian society in recent years, which is primarily related to the democratization of all areas of state activity, including law enforcement, require finding new approaches to reforming and staffing the National Police, including increasing the requirements for the professional activity of chiefs.

For a full study, first of all, one should refer to the definition of "chief". In the Great Interpretive Dictionary of Modern Ukrainian, the term "chief" is defined as "the one who controls someone, something, chiefs someone, something". In the Legal Encyclopedia, the term "chief" defines "an official who is vested with administrative authority over his or her collective and who manages it internally"2,3.

Professor Matiukhina N.P., in the terminology dictionary for personnel management of law-enforcement bodies of Ukraine, defines the chief of a person who is empowered to make managerial decisions and organize their implementation. It divides all chiefs into:

1) linear, who lead relatively separate systems and who not only coordinate the activities of subordinates and lower-level executives, but also make decisions regarding the strategy of system development, carry out the operational management of the entire activity of the system;

2) functional - chiefs of specialized services, departments and other units of all levels, whose responsibility is to prepare specific recommendations for line managers to make the latest decisions ${ }^{4}$.

For a full study of the concept of "chief", it would be advisable to study such categories as: "cadre" and "personnel", the definition of the content of which will help to characterize in more detail the category, which is outlined in the subject of our research.

\footnotetext{
${ }^{1}$ Великий тлумачний словник сучасної української мови / уклад. і гол. ред. В. Т. Бусел. Київ : ВТФ “Перун”, 2007. 1736 с.

2 Юридична енциклопедія / гол. редкол. Ю. С. Шемчушенко. Київ: Видавництво “Українська енциклопедія" імені М. П. Бажана, 2003. Т. 5. 733 с.

3 Юридичний словник / за ред. Б.М. Бабія, Ф.Г. Бурчака, В. М. Корецького, В. В. Цвєткова. Київ : Гол. ред. Укр. рад. енцикл., 1983. 872 с.

4 Термінологічний словник 3 управління персоналом органів внутрішніх справ України / Укладач Н. П. Матюхіна; за заг. ред. проф. О. М. Бандурки. Харків : Ун-т внутр. справ, 2000. 120 с.
} 
According to Academician Bandurka O.M. terms "cadre" and "personnel" are identical: "Cadre or personnel - is the main staff of the organization's employees who perform various organizational, technological and productioneconomic functions". Concerning the cadre of law-enforcement bodies, the scientist notes that they correspond to the following basic characteristics: they are persons who permanently or temporarily perform certain work functions in law-enforcement bodies (in their departments and institutions); performing such functions is foreseen by their main profession or specialty ${ }^{5}$.

In another aspect, the concept of "cadre" is considered by Plishkin V.M. according to which positions cadres of the Interior - a collection of individuals who serve as the primary occupation or profession regulatory official duties in the limits of regular number of organ or department of internal affairs and for receiving a reward in the form of salaries ${ }^{6}$.

Exploring the concept of "personnel", Pashkov O.S. notes that it brings together both "permanent" and "temporary" workers, representatives of both "qualified" and "unqualified" labor. He also emphasizes that, unlike personnel, they are full-time skilled workers who have previous professional training and have special knowledge, work skills or experience in their chosen field of activity ${ }^{7}$.

Describing the above concepts, we came to the conclusion that the concept of "personnel" in its content is much wider than the term "cadre"; cadre, according to the views of the majority of scientists, is a permanent staff of the organization, which occupies the positions envisaged by the staffing schedule, is responsible for their qualification characteristics to the job requirements and perform functions that require special professional training; personnel covers the notion of "cadre", as well as employees who work in the organization on a temporary basis, part-time or under a short-term employment contract. At the same time, the personnel include persons performing unqualified work that does not require special education or training.

The Disciplinary Statute of the National Police of Ukraine the term "chief" is also used, which means a police officer who is empowered to organize the official activities of subordinate police officers and other police officers and to control their official activities. In this legal act, executives are divided into direct, to which police officers are subordinate to the service, at least temporarily and directly. In turn, the nearest direct chief of subordinate is the subordinate's chief.

\footnotetext{
${ }^{5}$ Бандурка О. М. Управління в органах внутрішніх справ України: підручник. Харків : Унів. внутр. справ. 1998. 480 с.

${ }^{6}$ Плішкін В. М. Теорія управління органами внутрішніх справ : підручник / за ред.

Ю.Ф. Кравченка. Київ : Національна академія внутрішніх справ України. 1999. 702 с.

${ }^{7}$ Пашков О. С. Кадровая политика и право. Москва : Юрид. лит., 1989. 288 с.
} 
However, in the case of joint performance by police officers who are not subordinate to one another, the senior is considered to be a police officer designated by a direct supervisor or holding a senior position. If police officers occupy equal positions, the senior is determined by special rank $^{8}$.

The successful resolution of tasks assigned by the chief depends, first of all, on the personal qualities of the chief of the unit. As rightly points out Kulahin M.I., the chief "will be able to perform his functions successfully only if he presents a social model for his subordinates with his personal example and his behavior" ". We must also agree with the opinion of Selie H., who stated that "the choice of a place of work should start with the choice of a chief" ${ }^{\prime \prime}$.

As a result, it should be pointed out that the choice of the optimal variant of the managerial decision depends on the manager, the rational organization of work of the team, focused on the achievement of managerial goals. Managers are a kind of officials empowered by an administrative authority over a formally organized collective managed by them, who carry out internal organizational management of them.

The legal status of the chief of an organ or police department of Ukraine is enshrined in a number of normative documents: The Law of Ukraine "On the National Police of Ukraine", the Disciplinary Statute of the National Police of Ukraine, the Regulation on the Ministry of Internal Affairs of Ukraine; Order of the Ministry of Internal Affairs of Ukraine "On approval of the Rules of Ethical Conduct of Police".

According to the Law of Ukraine "On the National Police", the following managers of the system of the National Police of Ukraine are:

1) Minister of internal affairs;

2) the chief of the National Police of Ukraine;

3) chiefs of territorial bodies and units of the National Police of Ukraine $^{11}$.

Direct police leadership is exercised by the designated police chief who is assigned and dismissed by the Cabinet of Ministers of Ukraine upon the submission of the Prime Minister of Ukraine in accordance with the proposals

8 Дисциплінарний статут Національної поліції України : Закон України від 15 бер. 2018 p. № 2337-VIII. URL: https://zakon.rada.gov.ua/laws/show/2337-19 (дата звернення: 10.10.2019).

${ }^{9}$ Кулагин Н. И. Управление следственным аппаратом ОВД: автореф. дис. на здобуття наук. ступеня д-ра юрид. наук: 12.00.02. Москва : Акад. МВД Российской Федерации, 1990. $41 \mathrm{c}$.

${ }^{10}$ Бандурка О. М. Теорія і практика управління органами внутрішніх справ України : монографія. Харків : Основа, 2004. 780 с.

11 Про Національну поліцію: Закон України від 02 липн. 2015 р. № 580-VIII. URL: https://zakon.rada.gov.ua/laws/show/580-19 (дата звернення: 10.10.2019). 
of the Minister of Internal Affairs of Ukraine. The police chief has a first deputy and deputies, who are appointed to the post and dismissed by the Minister of Internal Affairs of Ukraine upon the submission of the Chief of Police.

A person may be appointed as the Chief and Deputy Chief of Police who: 1) meets the general conditions of entry into the police service; 2) has higher legal education; 3 ) has at least seven years of experience in the field of law; 4) Has at least five years of experience in management positions.

According to Art. 3 of the Disciplinary Statute of the National Police of Ukraine the chief is responsible for observing subordinate discipline and is obliged to: 1) create the conditions necessary for the performance of the police officer's subordinate duties; 2) respect the honor and dignity of subordinates, prevent violations of their rights and social guarantees; 3) develop a reasonable initiative and independence in the performance of duties as a police officer of subordinates; 4) to promote the development of subordinate level of qualification sufficient for the performance of official powers; 5) to study the individual and professional qualities of subordinates, ensuring transparency and objectivity in the assessment of their professional activity; 6) to ensure a favorable state of the moral and psychological climate in the team, to take timely actions to prevent the violation of official discipline of subordinates and the emergence of conflicts between them; 7) to control the observance of subordinate service discipline, to analyze its status and to report it objectively to the immediate supervisor, to carry out preventive work to strengthen the service discipline and to prevent the commission of subordinate offenses; 8) in case of violation of the subject of service discipline, take measures to end such violation and apply disciplinary punishment to the offender or initiate a request for the enforcement of the punishment by the authorized supervisor.

It should be emphasized that reforming the system of the Ministry of Internal Affairs of Ukraine, fulfilling the tasks envisaged by the Constitution and laws of Ukraine on protection of human rights and freedoms, combating crime, protection of public safety and order place new demands on the personal and professional qualities of the officers of the leading police force of the National Police of Ukraine cause the need to increase the value of their role in the police management system, the level of their managerial competence.

In this regard, the issue of qualitative and transparent selection of candidates for admission to the reserve of the leadership of the bodies of the National Police remains quite important. The main elements of this selection should be: an objective assessment of their personal and business 
qualities; training of reserve candidates; selection and appointment of the most suitable employees to the vacancies and analysis of their activities.

In addition, the chief of the police department should be clearly aware that his or her actions, behavior and activities depend to a large extent on the mental well-being of the subordinate staff and, therefore, his / her psychological health. The chief should act as an active subject of preserving the psychological health of his subordinates, for which he should have adequate psychological readiness for such activity, be a strong personality with a deep self-awareness, which manages his own emotional state and behavior. It is he who must be a balanced personality, able to successfully solve his personal problems and problems of the unit ${ }^{12}$.

In order to maintain the psychological health of the subordinate staff, the chief should be characterized by such traits as inner calmness, determination, openness, politeness, lack of fuss, flexibility of mind and consistency of behavior. At the same time, the chief should not be impulsive, irritable, irrepressible, aggressive, authoritarian, self-centered and self-interested ${ }^{13}$.

As Liaskovska O.A. notes, for effective management of people, a modern chief is obliged to have certain personal qualities that would give him the moral right to lead the team. These include: knowledge of job and function responsibilities; ability to choose methods for achievement of goals and increase of efficiency of functioning of organ; understanding the nature of management work and management processes; leadership capacity; the necessary skills in the management process of using modern means of communication; ability to perform special work in the management process of the National Police, etc. In the practical activity of the chief, such abilities are manifested in the ability to manage people and themselves, in the ability to teach and develop subordinates, the ability to understand people and form small groups, direct their activities; possess pedagogical techniques and skills, subtly and imperceptibly for the subordinates to teach them the task, bringing their professional qualification to the required standards ${ }^{14}$.

The chief of a body or unit of the National Police of Ukraine must, first of all, acquire a body of knowledge, skills and abilities that would enable: to

12 Конопльов В.В. Управлінські рішення в адміністративній діяльності органів внутрішніх справ: сутність та організаційно-правові питання підготовки і прийняття : монографія. Сімферополь : ХНУВС, ВДМВ “Таврія”, 2006. 356 с.

13 Барко В. І., Остапович В. П., Барко В. В. Вимоги до керівника як до суб’єкта збереження психологічного здоров'я поліцейських Національної поліції України. Право $i$ безпека. 2016. № 3 (62). С. 113-120.

14 Лясковська О. А. Керівник в органах і підрозділах Національної поліції України як організатор управління. Науковий вісник публічного та приватного права. 2017. № 3 . C. 114-118. URL: http://www.nvppp.in.ua/ vip/2017/3/24.pdf (дата звернення: 10.10.2019). 
ensure the functioning of the body or its structural unit in accordance with current conditions and requirements; to critically evaluate and predict economic, political, cultural and social events and phenomena; to understand modern problems of administrative activity and technology of administrative work; develop and implement new approaches and ideas; think analytically; be free to current legislation governing professional activity, as well as the proper filing of official documentation; combine fundamental knowledge with practice; use a modern methodology for the development, adoption and justification of management decisions, with mandatory consideration of universal values.

Thus, it is of utmost importance today that the National Police System of Ukraine has the most competent professional chiefs, capable of confirming the newest style of work and modern forms of management of the bodies and units of the National Police, and not just highly educated people with practical and life experience.

\section{Determination of the legal status and the role of the chief in the activities of the units of the National police of Ukraine}

The Law of Ukraine "On National Police" defines to a certain extent the legal status of such police posts as "police chief", "first deputy and deputy of police chief", "chiefs of territorial police bodies", "deputy chiefs of territorial police bodies", "police officers" who are the main categories of National Police officers.

There are different views among scholars on the category of "legal status" around which there is ongoing debate. To determine the legal status of a state body, Professor Komziuk A.T. considers it necessary to find out his place in the general system of executive power, the level and form of its legal regulation; to determine the limits of its competence, to determine the sphere of public relations regulated by this body, to list the objects, subordinate to it, to find out the range of tasks entrusted to it, the set of rights and responsibilities and its officials in the performance of the functions assigned to the body, that is, to determine the extent, possible behavior of the body and its officials in the performance of their functions (rights), as well as the extent of their mandatory behavior ${ }^{15}$.

According to the scientist Muzychuk O.M., determining the location and characteristics of the activities of any of the entities of legal relations is possible provided the analysis of their legal status and suggests under the legal

${ }^{15}$ Комзюк А. Т. Адміністративно-правові засоби здійснення митної справи : поняття та види. Вісник Харківського наџіонального університету внутрішніх справ. 2003. Вип. 22. URL: http://nbuv.gov.ua/UJRN/VKhnuvs_2003_22_41 (дата звернення: 10.10.2019). 
status of the entity of administrative and legal relations to understand the system of signs, which determine its role, place, enshrined in the legal acts. and appointments in the system of legal relations indicate its difference from other entities and the order of relations between them ${ }^{16}$.

The great legal dictionary defines that in Latin the term "status" means the position, status of something or anyone: "human status", "person status", "citizen status", "body status". Therefore, the term "status" applies to individuals and legal entities; this term is used by various industry sciences to study the structural elements of the subject of study of particular social relations ${ }^{17}$.

Concerning the definition of legal status, in the opinion of Volynky K.H., legal status is a system of interconnected rights and freedoms and responsibilities, which are enshrined in the law and determine the legal position of a person in society ${ }^{18}$.

According to Kravchuka M.V., the legal status of a person is the totality or system of all subjective legal rights, freedoms and duties, which determine the citizen's legal status in a society, which is enshrined in the current legislation and other forms of law ${ }^{19}$.

Therefore, legal status is a complex category, which contains complex structural elements, the main place among which is the rights and responsibilities of the subject (authority, competence).

Based on the analysis of the provisions of the Law of Ukraine "On the National Police", we believe that the legal status of the chief of units of the National Police is composed of the following elements: 1) the procedure for occupying the position of police chief; qualification requirements for the candidate (chief) for the respective position; 3) principles and guarantees of police service; 4) the authority and legal responsibility of the police chief; 5) grounds for dismissal from the position of police chief.

The decisive role of the chief of the National Police of Ukraine is that he is a decision-making authority. Having real power, the chief significantly influences his subordinates, and in general - the nature and results of the system. Skillful chief of the body clearly articulates the tasks of the staff, clearly understands their role in the process of their implementation, he is able

16 Музичук О. М. Уточнення сутності категорії “правовий статус” суб’єкта адміністративно-правових відносин та його елементного складу. Форум права. 2008. № 1 . C. 316-321.

${ }^{17}$ Большой юридический словарь / В. Н. Додонов и др.; под. ред. А. Я. Сухарева. Москва : Инфра-М, 1998. 790 с.

${ }^{18}$ Волинка К. Г. Теорія держави і права : навч. посіб. Київ : МАУП, 2003. 240 с.

${ }^{19}$ Кравчук М. В. Теорія держави та права. Проблеми теорії держави та права : навч. посіб. Вид. 3-те, змін. і доповнене. Тернопіль : Карт-бланш, 2002, 247 с. 
to find, identify and use the internal incentives of his subordinates and direct them to independent action, he is able to anticipate possible difficulties, prevent them from failure and find the best ways in each situation.

The chief of the National Police has a various but complementary functions. He also serves as an administrator, organizer, specialist, public figure and educator. In the activities of the chief of the National Police, these functions are implemented in such a close relationship that it is not always possible to distinguish how one function goes into another, but they are relatively independent ${ }^{20}$.

Bandurka O.M. points out rightly, "The activities of a modern chief are multifaceted. It combines the activities of defining the basic goals of the organization, as well as the ways to achieve them, the strategy of development: it is both influence on subordinates and performance of certain functions, both in relation to subordinates and the organization as a whole, and to other bodies". It follows that the daily activities of a chief can be reduced to performing such functions as: 1) administrative; 2) especially professional; 3) security; 4) educational; 5) control and supervision; 6) representative, etc ${ }^{21}$.

Practice management by the police demonstrates the need for timely and accurately recognize as the main chief, correct them see his ability to lead the team's future prospects.

The provisions of Art. 15 of the Law of Ukraine "On the National Police" defines the requirements that apply to the chief, the deputy chief of the territorial police body, namely: 1) meets the general conditions of entry into the police service; 2) has higher legal education; 3) has a minimum of five years of experience in the field of law; 4) Has at least one-year experience in management positions ${ }^{22}$.

According to Art. 21 of the Law of Ukraine "On the National Police", a person may be appointed as the chief and deputy chiefs of the police, who: 1) meets the general conditions for entering the police service; 2) has higher legal education; 3 ) has at least seven years of experience in the field of law; 4) has at least five years' experience in management positions.

The Ministry of Internal Affairs of Ukraine, with the purpose of forming in the police a sense of responsibility regarding observance of professional and ethical norms of behavior during the performance of official duties, as

${ }^{20}$ Дивак М. М. Шляхи вдосконалення форм управління якістю кадрового забезпечення Національної поліції в Україні. Вісник Харківського національного університету внутрішніх справ. 2012. № 1 (56). С. 175-181.

${ }^{21}$ Бандурка О. М. Теорія і практика управління органами внутрішніх справ України : монографія. Харків : Основа, 2004. 780 с.

22 Про Національну поліцію: Закон України від 02 липн. 2015 р. № 580-VIII. URL: https://zakon.rada.gov.ua/laws/show/580-19 (дата звернення: 10.10.2019). 
well as to promote strengthening of authority and trust of citizens to the National Police, the following orders were adopted, namely: "On approval Rules of Ethical Conduct of Police Officers" of 09.11.2016, No. 1179 and "On Approval of Rules of Ethical Conduct of the Employees of the Apparatus of the Ministry of Internal Affairs of Ukraine, Territorial Authorities, institutions and enterprises belonging to the Ministry of Internal Affairs" from 04.28.2016 267 p. 326237 number, which are in accordance with art. 37 of the Law of Ukraine "On Prevention of Corruption". These prescriptions are a generalized collection of professional and ethical requirements for police rules of conduct and are aimed at ensuring police service to the public by ensuring the protection of human rights and freedoms, combating crime, maintaining public safety and order on the basis of ethics and human values.

The chiefs of bodies of the National Police must comply with basic professional and ethical standards in their activities, which define the principles of ethics, which are: 1) honest service and loyalty to the state; securing state interests while performing the tasks and functions of the state; promoting the rights and legitimate interests of citizens and businesses; formation of a positive image of the state, including by changing the philosophy of business, where employees of the Ministry of Internal Affairs and the National Police are the center of security and guarantors of inviolability for law-abiding businessmen in conducting their business activities; 2) respect for the dignity of others; politeness and adherence to a high culture of communication; kindness and prevention of conflicts in relations with citizens; preventing, including out of work, actions and acts that may damage the work or adversely affect the reputation of the Interior Ministry and National Police; 3) focus on actions to protect public interests, prioritize the general good of the public over personal, private or corporate interests; inadmissibility of using state property for personal purposes; avoiding conflict between public and private interests; non-disclosure and non-use of information made known in connection with the fulfillment of the duties of the Ministry of Internal Affairs and National Police, including after the termination of its activity (except in cases prescribed by law); Preventing any benefits and showing affection for individuals and legal entities, political parties, public and religious organizations; 4) good faith in the implementation of decisions of the Verkhovna Rada of Ukraine, the President of Ukraine, the Cabinet of Ministers of Ukraine and state bodies in which the Ministry of Internal Affairs and National Police employees work, regardless of their own beliefs and political views; abstaining from any manifestations of public criticism of the activities of state bodies, their officials; correct attitude to the chiefs and employees of the state body in the performance of the duties of the Ministry of Internal Affairs and the National Police of their duties; 5) preventing the influence of political interests on the actions and decisions of the Ministry of Internal Affairs and National Police; refusal to publicly display political views 
and sympathies; compliance with the requirements for restrictions on political activity established by law for certain categories of police officers and the National Police; avoiding the use of symbolism by political parties in the performance of duties of the Ministry of Internal Affairs and of the National Police; ensuring transparency in relations with political actors; 6) openness and accessibility of information on the activities of the Ministry of Internal Affairs and National Police, except in cases specified by the Constitution and laws of Ukraine; 7) conscientious, honest and professional fulfillment of the duties of the Ministry of Internal Affairs and National Police, identification of initiative and creative abilities; constant improvement of the level of the professional competence and improvement of the organization of the activity; avoiding decision-making and responsibility for their actions and decisions.

The chief of police must meet the following general parameters: 1) knowledge of the legislation governing the activities of the National Police, knowledge and experience of working with regard to the specific authority, aspiration to improve their professional level, the ability to acquire knowledge independently; 2) psychological readiness for leadership, ability to make the most of the opportunities of subordinates, individual approach to subordinates, ability to distribute workload; 3 ) the ability to organize the work, the ability to really assess the situation, plan, implement the planned and exercise effective control; 4) mastering the skills of analyzing professional problems and tasks and finding ways to solve them, independent thinking, the ability to clearly, clearly and convincingly formulate their thoughts and ideas; 5) ability to communicate effectively with management, colleagues, subordinates and citizens, professional tact, mastering the basics of conflictology; 6) the ability to effectively and efficiently manage both in staff and in extreme situations, the ability to take on additional tasks in the case of urgent need, the willingness to make efforts to achieve a professional goal; 7) patriotism, self-criticism, honesty, self-esteem, culture of communication, tact, principle, impartiality, responsibility, desire to adhere to the norms of professional and professional ethics, etc.

One of the important areas of activity of the chief is the staffing of the police and the selection of candidates for enlistment in the reserve of the leadership of the National Police, the objective assessment of their business and personal qualities, the provision of training of candidates during their stay in the reserve, analysis of their activities and selection and appointment of the most suitable employees to the vacant positions ${ }^{23}$.

\footnotetext{
${ }^{23}$ Про затвердження Положення про порядок формування кадрового резерву на керівні посади в Міністерстві внутрішніх справ України, його територіальних органах та підрозділах: наказ Міністерства внутрішніх справ від 17 вер. 2012 р. № 808. URL: https://zakon.rada.gov.ua/laws/show/z1700-12 (дата звернення: 10.10.2019).
} 
The leading subject of personnel work in the bodies of the National Police is the Department of Personnel Assurance of the National Police, since it is the structural unit of the central government body of the National Police, which directly ensures the implementation of state policy on personnel and civil service in the staff of the National Police of Ukraine, territorial (interregional) bodies (establishments, institutions) of the National Police.

The main tasks of the Human Resources Department of the National Police in accordance with the current legislation of Ukraine are: staffing of police services; organizational, methodological and informational support of the work of police departments; ensuring the organization of work on the selection, study and staffing of police bodies with qualified personnel; the organization and methodological provision of special training for the first time recruited police officers in order to acquire the knowledge and skills necessary for the performance of police powers, as well as the training and retraining of police officers; organization of vocational training and internships, psychological support systems for police and National Police officers; ensuring that organizational and staffing activities are carried out by the National Police, optimal allocation and effective use of the existing staffing of the police to carry out the tasks and functions assigned to it; organization of work on strengthening of discipline and legality in activity of police officers, carrying out of service investigations, etc.

In connection with this, the leadership of the National Police of Ukraine is carrying out a number of organizational measures aimed at optimizing the structure and improving the quality of its personnel. Considerable work is reflected in forms of personnel management, among which there are general forms that are characteristic of all spheres of management, and special ones that can be found only in the field of research.

General forms include publication of regulations; publication of individual (legal, administrative) acts; implementation of other legally significant actions, organizational actions and logistical operations.

Special forms of personnel management include the following: a) identifying staffing needs (forecasting new jobs, scheduling staffing and quality staffing, selecting methods for calculating staffing requirements); b) career guidance with candidates for the service (analysis of sources of selection of personnel, selection of personnel, establishment of contacts with external organizations, business evaluation of personnel during selection) ${ }^{24}$.

In order to effectively manage people, a modern chief must have such personal qualities that would give him the moral right to lead the team ${ }^{25}$.

\footnotetext{
${ }^{24}$ Коруля І. В. Роль керівника у системі управління ОВС. Юридичний вісник. 2014. № 2. C. $63-68$.

25 Барко В. I. Професійний відбір кадрів до Національної поліції (психологічний аспект) : монографія. Київ : Ніка-Центр, 2002. 296 с.
} 
For example, the knowledge and ability to perform specialized work in the field of management of the National Police, which include an understanding of the nature of management work and management processes; knowledge of job and function responsibilities, ways to achieve goals and increase the effectiveness of the body; ability to use modern information technology and communication tools required in the management process; leadership skills. In the practical activity of the chief, these abilities are manifested in the ability to manage people and themselves, in the ability to educate and develop subordinates, the ability to understand people and form small groups, direct their activities; to have pedagogical techniques and skills subtly and unnoticeably for the subordinates to teach them the task, bringing their professional qualification to the required standards ${ }^{26}$.

Thus, the chief, influencing the subordinates, must be aimed at prompting them to certain service behavior that would meet both the requirements of the unit and his own ideas. Today, it is very important that management staff not only have highly educated people with life and practical experience, but competent employees who are able to confirm the modern style of work and to master the latest forms of management of police bodies and units.

The chief of the National Police must first of all possess a body of knowledge and skills that would enable: to provide the organ or its structural unit with the modern economic, political and social conditions and requirements; to combine knowledge of fundamental issues with practice, to have a modern methodology of substantiation of managerial decisions taking into account universal values, interests of the individual, society and the state; be free to navigate the legislation relating to the field of professional activity; critically evaluate and predict political, economic, social, cultural events and phenomena; to think analytically, to understand modern problems of management, technologies of administrative work, to produce new ideas, managerial decisions; to have the style of official documents and so on.

An important prerequisite for qualitative selection for managerial positions is the development and implementation of personnel management models of management activities of management personnel.

The model includes four components: 1) theoretical and methodological: knowledge of management theory and methodology; 2) practical: professional knowledge, interests and requests; setting and solving target settings; formation and improvement of intellectual, practical skills; creative orientation; self-regulation, self-improvement, self-education; 3) organizational: knowledge of methods and techniques of management; HR; application of the latest methods and technologies; software and information and

26 Барко В. І. Професійний відбір кадрів до Національної поліції (психологічний аспект) : монографія. Київ : Ніка-Центр, 2002. 296 с. 
communication support; innovative, experimental and scientific activity; 4) psychological: individual professional abilities; work and special experience; business, moral, ideological qualities; ideals; cultural norms.

The structure of the model has three main elements: the area of competence that underlies the managerial competence; the scope of the qualities that are necessary for the chief in each area, and the key characteristics of the chief's activities and behavior according to the qualification requirements. Using the model of managerial competence provides a methodological basis for identifying potential chiefs, developing training programs, drawing up plans for the professional development of executives, appointing the most suitable employees for a specific position. Also, a significant layer of competence of the chief of the National Police should be the authority on the organization of service in the National Police, since they allow to apply at the level with the methods of direct influence (orders, orders, etc.), and measures to encourage and encourage the National Police to properly perform their duties.

It is also necessary to mention the application of an administrative contract aimed at the effective resolution of managerial tasks to support discipline in the exercise of authority by the chief of the National Police, guarantee national and public order. Chiefs who regulate managerial relations through an administrative contract have to ensure that this goal is achieved, while maximizing their power over third parties while acting within their competence, fulfilling the tasks assigned to them. Accordingly, in the sole decision-making process, the chief of the body has the right to sign the contract, if it is expressly provided for by law or within its competence. In addition to the chief, the contract may be signed by an official who has been granted the right to sign by a special document (order, power of attorney, order, etc. $)^{27}$.

The systematic reform of law enforcement agencies in Ukraine in the direction of improving personnel work should be aimed at solving the following priority tasks: organization of work with personnel based on the use of the achievements of science, best domestic and foreign experience; implementation of measures for introducing contract and competitive recruitment of personnel to the National Police, improving the qualification requirements for candidates and employees, improving the efficiency of the system of professional and psychological training of staff; improvement of the normative base of personnel work, creation of

27 Тимчишин Т. М. Окремі аспекти використання адміністративного договору в регулюванні відносин державного управління. Науковий вісник Львівського державного університету внутрішніх справ. 2016. № 1. С. 217-225. 
an optimal system of scientific and methodological and informational support of work with personnel; improving the management of personnel processes on the basis of a modern system of scientific-analytical and information support; training of qualified and competent personnel for police units; realization of social rights and guarantees of employees; adjusting the number of employees in accordance with regulatory loads; creation of an effective mechanism of mutual responsibility of educational institutions and practical units for the quality of selection of candidates for training; scientific determination of the needs of the police in specialists of different specialties and specializations with standardization of state standards for their preparation.

Thus, police officers are referred to officials who, on a regular basis and within their powers, manage the bodies and units of the National Police, have a specific mission and a dedicated subordinate team, in which they carry out their management functions; are responsible to society for their activities; in the relations with the population are professional workers, direct representatives of the state power and holders of state-power powers.

To summarize, we would like to point out that we have offered the suggestions on the main areas of work of the chief of units of the National Police; requirements for their professional, organizational, managerial and moral-psychological qualities; the formation of a staff reserve, etc., if used, will help to improve the effectiveness of the management of units of the National Police as a whole.

\section{CONCLUSIONS}

We refer to police chiefs as officials who, on a regular basis and within their powers, manage the bodies and units of the National Police, have a specific mission and a dedicated subordinate team in which they carry out their managerial functions; are responsible to society for their activities; in the relations with the population are professional workers, direct representatives of the state power and holders of state-power powers.

The National Police System of Ukraine should have competent professional chiefs, capable of confirming the latest style of work and modern forms of management of bodies and units of the National Police, and not just highly educated people with practical and life experience.

Thus, suggestions we have offered above on the main areas of work of the chief of units of the National Police; requirements for their professional, organizational-managerial and moral-psychological qualities; the formation of a staff reserve, etc., if used, will help to improve the effectiveness of the management of units of the National Police as a whole. 


\section{SUMMARY}

The article is devoted to the study of the legal status of the chief of units of the National Police of Ukraine. Theoretical approaches to the definition and correlation of the terms "chief", "personnel" and "staff" are investigated. The concept of "legal status" is defined and the elements of "legal status" of the chief of units of the National Police of Ukraine are characterized. Requirements submitted to the chief of a territorial police body are analyzed. It is justified what criteria are put forward to the chief of the National Police. The main tasks of the Human Resources Department of the National Police in accordance with the current legislation of Ukraine have been clarified. General and special forms of personnel management in the bodies of the National Police of Ukraine are revealed.

\section{REFERENCES}

1. Дисциплінарний статут Національної поліції України : Закон України від 15 бер. 2018 р. № 2337-VIII. URL: https://zakon.rada.gov.ua/ laws/show/2337-19 (дата звернення: 10.10.2019).

2. Про Національну поліцію : Закон України від 02 липн. 2015 р. № 580-VIII. URL: https://zakon.rada.gov.ua/laws/show/580-19 (дата звернення: 10.10.2019).

3. Про затвердження Положення про порядок формування кадрового резерву на керівні посади в Міністерстві внутрішніх справ України, його територіальних органах та підрозділах : наказ Міністерства внутрішніх справ від 17 вер. 2012 р. № 808. URL: https://zakon.rada.gov.ua/laws/ show/z1700-12 (дата звернення: 10.10.2019).

4. Бандурка О. М. Теорія і практика управління органами внутрішніх справ України : монографія. Харків : Основа, 2004. 780 с.

5. Бандурка О.М. Управління в органах внутрішніх справ України: підручник. Харків : Унів. внутр. справ. 1998. 480с.

6. Барко В. І. Професійний відбір кадрів до Національної поліції (психологічний аспект) : монографія. Київ : Ніка-Центр, 2002. 296 с.

7. Барко В.І., Остапович В.П., Барко В.В. Вимоги до керівника як до суб'єкта збереження психологічного здоров'я поліцейських Національної поліції України. Право і безпека. 2016. № 3 (62). С. 113-120.

8. Большой юридический словарь / В.Н. Додонов и др.; под. ред. А.Я. Сухарева. Москва : Инфра-М, 1998. 790 с.

9. Великий тлумачний словник сучасної української мови / уклад. і гол. ред. В.Т. Бусел. Київ : ВТФ “Перун”, 2007. 1736 с.

10. Волинка К.Г. Теорія держави і права : навч. посіб. Київ : МАУП, 2003. $240 \mathrm{c}$. 
11.Дивак М.М. Шляхи вдосконалення форм управління якістю кадрового забезпечення Національної поліціївУкраїні. Вісник Харківського національного університету внутрішніх справ. 2012. № 1 (56). C. 175-181.

12. Комзюк А.Т. Адміністративно-правові засоби здійснення митної справи : поняття та види. Вісник Харківського національного університету внутрішніх справ. 2003. Вип. 22. URL: http://nbuv.gov.ua/UJRN/ VKhnuvs_2003_22_41 (дата звернення: 10.10.2019).

13. Конопльов В.В. Управлінські рішення в адміністративній діяльності органів внутрішніх справ: сутність та організаційно-правові питання підготовки і прийняття : монографія. Сімферополь : ХНУВС, ВДМВ “Таврія”, 2006. 356 с.

14. Коруля І. В. Роль керівника у системі управління ОВС. Юридичний вісник. 2014. № 2. С. 63-68.

15. Кравчук М.В. Теорія держави та права. Проблеми теорії держави та права : навч. посіб. Вид. 3-тє, змін. і доповнене. Тернопіль : Картбланш, 2002, $247 \mathrm{c.}$

16. Кулагин Н.И. Управление следственным аппаратом ОВД: автореф. дис. на здобуття наук. ступеня д-ра юрид. наук: 12.00.02. Москва : Акад. МВД Российской Федерации, 1990. 41 с.

17. Лясковська О.А. Керівник в органах і підрозділах Національної поліції України як організатор управління. Науковий вісник публічного та приватного права. 2017. № 3. С. 114-118. URL: http://www.nvppp.in.ua/vip/2017/3/24.pdf (дата звернення: 10.10.2019).

18. Музичук О.М. Уточнення сутності категорії "правовий статус" суб'єкта адміністративно-правових відносин та його елементного складу. Форум права. 2008. № 1. С. 316-321.

19. Пашков О.С. Кадровая политика и право. Москва : Юрид. лит., 1989. $288 \mathrm{c}$.

20.Плішкін В.М.Теорія управління органами внутрішніх справ : підручник / за ред. Ю.Ф. Кравченка. Київ : Національна академія внутрішніх справ України. 1999. 702 с.

21. Термінологічний словник 3 управління персоналом органів внутрішніх справ України / Укладач Н. П. Матюхіна; за заг. ред. проф. О.М.Бандурки. Харків : Ун-т внутр. справ, 2000. 120 с.

22. Тимчишин Т.М. Окремі аспекти використання адміністративного договору в регулюванні відносин державного управління. Науковий вісник Львівського державного університету внутрішніх справ. 2016. № 1. C. 217-225. 
23. Юридична енциклопедія / гол. редкол. Ю.С. Шемчушенко. Київ: Видавництво "Українська енциклопедія" імені М.П. Бажана, 2003. T. $5.733 \mathrm{c}$.

24. Юридичний словник / за ред. Б.М. Бабія, Ф.Г. Бурчака, В.М. Корецького, В.В. Цвєткова. Київ : Гол. ред. Укр. рад. енцикл., 1983. $872 \mathrm{c}$.

\section{Information about the author:}

Izbash K. S.,

Candidate of Law, Associate Professor,

Senior Researcher at the Department of Organization of Scientific Work,

Odessa State University of Internal Affairs 1, Uspenskaia str., Odesa, 65000, Ukraine 